\title{
Typifications of Malesian Putranjivaceae
}

\author{
G.A. Levin ${ }^{1,2,3}$ \\ ${ }^{1}$ Illinois Natural History Survey, Prairie Research Institute, \\ University of Illinois, 1816 S Oak St., Champaign, Illinois 61820, USA \\ levin1@illinois.edu \\ ${ }^{2}$ Canadian Museum of Nature, PO Box 3443 Stn "D”, \\ Ottawa, Ontario K1P 6P4, Canada \\ ${ }^{3}$ Naturalis Biodiversity Centre, PO Box 9517, \\ 2300 RA Leiden, The Netherlands
}

\begin{abstract}
A review of names and types in Putranjivaceae relevant to Malesia has been undertaken. Fifty-six lectotype designations (including three second-step lectotypifications) and four neotype designations are given. In addition, a previous lectotypification is discussed.
\end{abstract}

Keywords. Anaua, Calyptosepalum, Cyclostemon, Drypetes, Elaeocarpus, Hemicyclia, Hydnocarpus, Malesia

\section{Introduction}

While preparing treatments of Putranjivaceae for Flora Malesiana, the Flora of Singapore, and the Flora of Peninsular Malaysia, I realised that many of the relevant scientific names lacked holotypes and that few of these had been lectotypified, despite a long history of taxonomic work on the Malesian members of the family, especially by Airy Shaw (e.g., Airy Shaw 1975, 1980a,b, 1981, 1982, 1983). In many cases, the original authors did not designate holotypes, and in a few cases, taxa were described exclusively from living material or I could locate no original material, necessitating neotypification. Many of the names were published by E.D. Merrill and others based at PNH (herbarium acronyms follow Thiers, continuously updated) or by F. Pax and K. Hoffmann at B; both herbaria were destroyed during World War II, so any original material in them was lost. Three names that previously had been lectotypified required second-step lectotypification to designate specific specimens. Here I designate lectotypes or neotypes for nearly all the names without holotypes, but for a few names I have yet to locate suitable material and will designate types in the future. I also discuss a previous lectotypification by other authors.

Names are listed alphabetically by their original name, followed by any later combinations. Names that I currently accept are shown in bold; this synonymy follows previous authors, especially Airy Shaw in his papers cited above, but my further work on some species groups may lead to changes in accepted names. I have seen all specimens cited unless indicated otherwise; those I have seen only as an online image are designated with an asterisk (*). When more than one barcode is listed, they represent different specimens unless noted otherwise. 


\section{New lectotypifications and neotypifications}

1. Calyptosepalum sumatranum S.Moore, J. Bot. 63(Suppl.): 92 (1925), non Drypetes sumatrana (Miq.) Pax \& K.Hoffm. (1922). - Drypetes calyptosepala Airy Shaw, Kew Bull. 29: 301 (1974). - TYPE: [Indonesia], Sumatra, Palembang Province, foot of Mt Kaba, 3000 ft [900 m], 1880, H.O. Forbes 2847 (lectotype BM [BM001191730*], first step designated by Bailey \& Smith, J. Arnold Arbor. 34: 59 (1953), second step designated here; isolectotypes GH [GH00055899], K [K000854229], L [L0016171, L0016172]). Remaining syntypes: [Indonesia], Sumatra, Palembang Province, Ayar Angat, near Mt Kaba, $2500 \mathrm{ft}$ [760 m], 1881-1882, Forbes 2862 (BM[BM001191729*], K [K000854228], L [L0016173]).

Notes. Moore (1925) cited two gatherings in the protologue, Forbes 2847 and Forbes 2862. Although he implied that Forbes 2847 was the type, Moore did not use the term "type" and therefore both gatherings must be regarded as syntypes. Bailey \& Smith (1953) cited the specimen at GH as an "isotype". Under Art. 9.10 of the Shenzhen Code (Turland, et al., 2018), that might be considered correctable to "lectotype". However, it is here interpreted to mean that Bailey \& Smith thought the "holotype" (effectively the lectotype) was elsewhere. Still, under Art. 9.17, that was a first-step leptotypification, making Forbes 2847 the type gathering. I have designated as the second-step lectotype the specimen at BM because it is in the best condition of the specimens I have seen; coincidentally, BM is where Moore was located, and the specimen there possibly was the only one from that gathering seen by him.

2. Cyclostemon bordenii Merr., Publ. Bur. Sci. Gov. Lab. 17: 26 (1904). - Drypetes bordenii (Merr.) Pax \& K.Hoffm. in Engler (ed.), Pflanzenr. IV, fam. 147 (Heft 15): 244 (1922). - TYPE: Philippines, Bataan, Luzon, Lamao River, February 1904, P.T. Barnes For. Bur. 333 (lectotype US [US00109928], designated here; isolectotypes F [F0092314F], NY [NY02684319]).

= Drypetes longifolia (Blume) Pax \& K.Hoffm. in Engler (ed.), Pflanzenr. IV, fam. 147 (Heft 15): 245 (1922).

Notes. Only a single gathering was cited in the protologue; I have designated as the lectotype the best syntype I have located.

3. Cyclostemon calcicola Merr., Philipp. J. Sci., C 9: 478 (1915 ['1914’]). - Drypetes calcicola (Merr.) Pax \& K.Hoffm. in Engler (ed.), Pflanzenr. IV, fam. 147 (Heft 15): 266 (1922). - TYPE: Philippines, Palawan, Taytay Bay, Apulit Island, 10 m, 31 May 1913, E.D. Merrill 9430 (lectotype US [US00109929], designated here; isolectotypes BRI [BRI-AQ0342524*], CM [CM1264*], K [K000854315]).

= Drypetes ovalis (J.J.Sm.) Pax \& K.Hoffm. in Engler (ed.), Pflanzenr. IV, fam. 147 (Heft 15): 269 (1922). 
Notes. Only a single gathering was cited in the protologue. I designate as the lectotype the syntype at US because it shows the leaf and fruit characteristics that Merrill thought distinguished this species.

4. Cyclostemon calocarpus Hook.f., F1. Brit. India 5: 343 (1887). - [Aporosa calocarpa Kurz ex Hook.f., Fl. Brit. India 5: 343 (1887), nom. inval., pro syn.] Drypetes calocarpa (Hook.f.) Pax \& K.Hoffm. in Engler (ed.), Pflanzenr. IV, fam. 147 (Heft 15): 251 (1922). - TYPE: India, Andaman Islands, South Andaman Island, north coast, S. Kurz S.n. (lectotype (or perhaps holotype) K [K000246649], designated here; isolectotypes (or perhaps isotypes) CAL [CAL0000022986, CAL0000022987]).

= Drypetes longifolia (Blume) Pax \& K.Hoffm. in Engler (ed.), Pflanzenr. IV, fam. 147 (Heft 15): 245 (1922).

Notes. Only a single gathering was cited in the protologue; I have designated as the lectotype the only specimen at K, where most of the specimens Hooker used for The Flora of British India are located. Although this might be considered the holotype, I follow the recommendation of McNeill (2014) in designating it as the lectotype.

5. Cyclostemon castilloi Merr., Philipp. J. Sci. 21: 522 (1922). - Drypetes castilloi (Merr.) Merr., Univ. Calif. Publ. Bot. 15: 140 (1929). - TYPE: [Malaysia, Sabah], Sandakan District, Suanlamba watershed, 26 August 1918, Castillo 637 (lectotype K [K000854227], designated here).

Notes. Only a single gathering was cited in the protologue; I designate as the lectotype the only syntype I have been able to locate.

6. Cyclostemon cumingii Baill. ex Müll.Arg in DC., Prodr. 15(2): 485 (1866).-Drypetes cumingii (Baill. ex Müll.Arg.) Pax \& K.Hoffm. in Engler (ed.), Pflanzenr. IV, fam. 147 (Heft 15): 238 (1922). - TYPE: Philippines, [Samar], [1837], H. Cuming 1695 (lectotype G-DC [G00318476], designated here; isolectotypes BM [BM001191828*], $\mathrm{G}$ [G00434752], K [K000854277, K000854278], L [L0016176, L0016177], M [M0265532*], P [P02428316, P05600171, P05600172]).

Notes. Baillon (1858: 562) published the name Cyclostemon cumingii (as 'cummingii') and cited Cuming 1695, but provided no description or diagnosis; the species was first described by Müller, who cited the same gathering. The specimen at G-DC is the most complete of those that might have been seen by Müller, so I have designated it as the lectotype. Although most duplicates state only "Philippines", according to the number (Merrill, 1915) and a few labels, the specimens are from Samar, which Cuming visited in 1837 . 
7. Cyclostemon curtisii Hook.f., Fl. Brit. India 5: 343 (1887). - Drypetes curtisii (Hook.f.) Pax \& K.Hoffm. in Engler (ed.), Pflanzenr. IV, fam. 147 (Heft 15): 250 (1922). - TYPE: [Malaysia], Penang, Monisto Road, $2500 \mathrm{ft}$ [760 m], October 1886, C. Curtis 1023 (lectotype (or perhaps holotype) K [K000854219, K000854220 - one specimen over two sheets], designated here; isolectotype (or perhaps isotype) SING [SING0050219]).

Notes. Only a single gathering was cited in the protologue; I have designated as the lectotype the only specimen at $\mathrm{K}$, where most of the specimens Hooker used for The Flora of British India are located. Although this might be considered the holotype, I follow the recommendation of McNeill (2014) in designating it as the lectotype.

8. Cyclostemon ellipsoideus Merr., Philipp. J. Sci., C 9: 369 (1914). - Drypetes ellipsoidea (Merr.) Pax \& K.Hoffm. in Engler (ed.), Pflanzenr. IV, fam. 147 (Heft 15): 250 (1922). - TYPE: Philippines, Leyte, Buenavista, near Jaro, 500 m, 10 June 1914, C.A. Wenzel 828 (lectotype A [A00055903], designated here; isolectotypes BM, GH [GH00055904], US [US00109930]).

Notes. Only a single gathering was cited in the protologue. I have designated the syntype at A as the lectotype because it is the most complete. Although Merrill (1914) gave the collection date as 3 Jun 1914, the specimens at A and GH say 10 Jun 1914 and the specimen at US says May-Jul 1914. None of the duplicates give a location more specific than "Leyte" but Merrill (1914) gave more complete information.

9. Cyclostemon falcatus Merr., Philipp. J. Sci., C 3: 415 (1909 ['1908']). - Drypetes falcata (Merr.) Pax \& K.Hoffm. in Engler (ed.), Pflanzenr. IV, fam. 147 (Heft 15): 250 (1922). - TYPE: Philippines, [Cagayan Province], Babuyan Islands, Camiguin Island, 22 June 1907, E. Fénix Bur. Sci. 4033 (lectotype K [K000854316], designated here; isolectotype US [US00109931]).

Notes. Only a single gathering was cited in the protologue; I have designated as the lectotype the better of the two syntypes I located. The exact collection date is from the protologue; the existing specimen labels say "June-July 1907".

10. Cyclostemon gitingensis Elmer, Leafl. Philipp. Bot. 3: 912 (1910). - Drypetes gitingensis (Elmer) Pax \& K.Hoffm. in Engler (ed.), Pflanzenr. IV, fam. 147 (Heft 15): 250 (1922). - TYPE: Philippines, Capiz Province, Sibuyan, Magallanes, Mt GitingGiting, along Sinuban Creek, 1000 ft, April 1910, A.D.E. Elmer 12317 (lectotype NY [NY2684333], designated here; isolectotypes A [A00055905], E [E00394977*], GH [GH00055906], HBG [HBG516334*], K [K000854317], L [L0154889], U [U.1602127], US [US00109932]). 
Notes. Only a single gathering was cited in the protologue; I have designated the syntype at NY as the lectotype because it is complete and has a typed copy of Elmer's field notes attached.

11. Cyclostemon globosus Merr., Philipp. J. Sci., C 9: 478 (1915 ['1914’]). - Drypetes globosa (Merr.) Pax \& K.Hoffm. in Engler (ed.), Pflanzenr. IV, fam. 147 (Heft 15): 247 (1922). - TYPE: Philippines, Palawan, Cuyo, 20 July 1913, L. Escritor Bur. Sci. 21362 (lectotype NY [NY2684335], designated here; isolectotypes F [F0092311F], K [K000854268], L [L0154893], SING [SING0050222], US [US00109933]).

Notes. Only a single gathering was cited in the protologue. Most of the syntypes I found have only detached fruits in a packet, but the specimens at L, NY, and SING have some fruits attached. Among these, the specimen in the best condition is at NY, so I have designated that as the lectotype.

12. Cyclostemon grandifolius C.B.Rob., Philipp. J. Sci., C 3: 197 (1908). - Drypetes grandifolia (C.B.Rob.) Pax \& K.Hoffm. in Engler (ed.), Pflanzenr. IV, fam. 147 (Heft 15): 245 (1922). - TYPE: Philippines, Mindanao, Zamboanga District, Lumbiag, 40 m, 22 February 1907, W.I. Hutchinson For. Bur. 6554 (lectotype US [US00109934], designated here).

Notes. Only a single gathering was cited in the protologue; I have designated as the lectotype the only syntype that I could locate. The lectotype gives the collection date as "Mar. 1907" rather than 22 Feb 1907 as given in the protologue.

13. Cyclostemon incarnatus Elmer, Leafl. Philipp. Bot. 7: 2639 (1915), as 'incarnata'. - TYPE: Philippines, Mindanao, Agusan, Cabadbaran (Mt Urdaneta), July 1912, A.D.E. Elmer 13265 (lectotype NY [NY02684345], designated here; isolectotypes A [A01166333], G [G00434742, G00434743], GH [GH00055907], HBG[HBG516306*], K [K000854264], L [L0154939], P [P05608682], U [U.1602142], US [US00109935]). = Drypetes longifolia (Blume) Pax \& K.Hoffm. in Engler (ed.), Pflanzenr. IV, fam. 147 (Heft 15): 245 (1922).

Notes. Only a single gathering was cited in the protologue. I have designated the specimen at NY as the lectotype because it is among the best of the syntypes I located and it has a typed copy of Elmer's field notes attached.

14. Cyclostemon iwahigensis Elmer, Leafl. Philipp. Bot. 4: 1278 (1911). - TYPE: Philippines, Palawan, Brooks Point (Addison Peak), February 1911, A.D.E. Elmer 12695 (lectotype NY [NY2684325], first step designated by Merrill, Enum. Philipp. 
Fl. Pl. 2: 407 (1923), second step designated here; isolectotypes E [E00310653*], G [G00434741], HBG [HBG516328*], K [K000854276], L [L.2207910], U [U.1602133]).

= Drypetes cumingii (Baill. ex Müll.Arg.) Pax \& K.Hoffm. in Engler (ed.), Pflanzenr. IV, fam. 147 (Heft 15): 238 (1922).

Notes. Elmer cited two syntypes for Cyclostemon iwahigensis. One of these, Elmer 13175, is Hydnocarpus heterophyllus Blume subsp. philippinensis Sleumer (Merrill, 1923; Sleumer, 1954). The other was designated as the first-step lectotype by Merrill (1923); he and Elmer (1911) gave the number as 12696, but that is in error. I have chosen the specimen at NY as the second-step lectotype because it is complete and is accompanied by a typed version of Elmer's field notes.

15. Cyclostemon littoralis C.B.Rob., Philipp. J. Sci., C 3: 198 (1908). - Drypetes littoralis (C.B.Rob.) Merr., Philipp. J. Sci. 29: 380 (1926). - TYPE: Philippines, Bataan Province, Luzon, Mt Mariveles, Lamao River, along coast, 30 December 1903, R.S. Williams 377 (lectotype (or perhaps holotype) NY [NY02684326], designated here; isolectotypes (or perhaps isotypes) GH [GH01166334], K [K000854275], US [US00109936]).

Notes. In the introduction to the paper where he described Cyclostemon littoralis, Robinson (1908) stated that he studied material at NY collected by Williams, but that some duplicates were sent to $\mathrm{PNH}$; he did not state where the types were located, but any material that was at PNH presumably was destroyed. He cited Williams 377 as the type, and the specimen at NY possibly could be regarded as the holotype.

16. Cyclostemon longifolius Blume, Bijdr. Fl. Ned. Ind. 598 (1826), as 'longifolium'. - Drypetes longifolia (Blume) Pax \& K.Hoffm. in Engler (ed.), Pflanzenr. IV, fam. 147 (Heft 15): 245 (1922). - TYPE: [Indonesia], Java, "in sylvis montis salassie Provinciae Tjanjor", C.L. Blume s.n. (lectotype L [L.2213344], designated here; possible isolectotype NY [NY02684343]).

Notes. Blume (1825-1826) described Cyclostemon longifolius (as 'longifolium') and C. macrophyllus (as 'macrophyllum') simultaneously, giving different collection localities, blooming times, and vernacular names for the two species. He differentiated them on the basis of the former having leaves with rounded bases, acute apices, and minutely serrulate distal margins and the latter having leaves with somewhat acute bases, acuminate apices, and entire margins. There are four specimens at $\mathrm{L}$ that could be Blume's original material, but none have the locality given more specifically than Java. One (L.2213344) has the leaf base and apex shapes he attributed to Cyclostemon longifolius; although the margin is entire, the distal part of the leaf has a few small undulations that Blume could have interpreted as serrulation. That specimen is labelled 
"Cyclostemon longifolium" in what appears to be Blume's handwriting and I have designated it as the lectotype of $C$. longifolius. The specimen cited above from NY is attributed to Blume and matches the morphology of the lectotype, but none of the label appears to be in Blume's hand.

17. Cyclostemon macrophyllus Blume, Bijdr. Fl. Ned. Ind. 598 (1826), as 'macrophyllum'. - Drypetes macrophylla (Blume) Pax \& K.Hoffm. in Engler (ed.), Pflanzenr. IV, fam. 147 (Heft 15): 247 (1922). - TYPE: [Indonesia], Java, "in sylvis montis Salak", C.L. Blume s.n. [2114] (lectotype L [L.2213342], designated here; isolectotypes L [L.2213343], NY [NY02684344]).

= Drypetes longifolia (Blume) Pax \& K.Hoffm. in Engler (ed.), Pflanzenr. IV, fam. 147 (Heft 15): 245 (1922).

Notes. As I discussed in my note regarding Cyclostemon longifolius, Blume (18251826) described that species (as 'longifolium') and C. macrophyllus (as 'macrophyllum') simultaneously, differentiating them on the basis of a series of leaf characters and stating that they came from different locations in Java. The four specimens at $L$ that could be Blume's original material lack specific locality information, but three specimens have the morphology he attributed to C. macrophyllus. One of these (L.2213342), which consists of a leafy branch and three detached leaves, has a label in what appears to be Blume's handwriting giving the scientific name "Cyclostemon macrophyllum", the vernacular name Blume (1825-1826) gave for that species, and the number " 2114 ". I have designated that specimen as the lectotype of Cyclostemon macrophyllus. The second of these specimens (L.2213343) consists of four detached leaves that are indistinguishable from the leaves of L.2213342, but it has only a Herb. Lugd. Bat. label attributing the specimen to Blume and Java; it probably is an isolectotype. The last specimen (L.2213354) has leaves that are darker and tend to be narrower than those of the previous two specimens and bears a handwritten label, not in Blume's hand, saying "Cyclostemon macrophyllus, Java, Herb. Dr. Bl.". Given its different appearance and clearly later labelling (note that the gender of the epithet has been corrected from Blume's original, incorrect one), this specimen likely is not original material. The specimen from NY cited as an isolectotype is also numbered 2114 but is not in as good condition as the specimen at L that I have designated as the lectotype. Two specimens at P (P05600150, P05600151) are attributed to Blume and have the morphology of the lectotype, but do not bear any number; it is possible that they are isolectotypes. There is a specimen at BM bearing a label printed with "Communicat. ex Herb. Lugduno-Batavo" and handwritten information indicating the collection is by Blume and from Java, but it bears the number 233 and therefore should be treated as from a separate gathering.

Priority of Cyclostemon longifolius over C. macrophyllus was established by Moore (1925: 97), the first person to synonymise the two names. 
18. Cyclostemon macrophyllus var. malaccensis Hook.f., Fl. Brit. India 5: 341 (1887). - TYPE: [Malaysia], Malacca, 17 July 1867, A.C. Maingay 1874 [Kew distribution no. 1430] (lectotype K [K001235486], designated here; isolectoype L [L.2207993]). Remaining syntypes: same locality as lectotype, Maingay s.n. [Kew distribution no. 1435] (K [K001235485]); ibidem, 19 September 1868, Maingay 3349 [Kew distribution no. 1435] (K [K001235484]).

= Drypetes longifolia (Blume) Pax \& K.Hoffm. in Engler (ed.), Pflanzenr. IV, fam. 147 (Heft 15): 245 (1922).

Notes. When he described Cyclostemon macrophyllus var. malaccensis, Hooker (1887) listed three syntypes, all collected by Maingay in Malacca. Two of the specimens (1435 and 3349) are staminate, but the stamens have all been destroyed by insects. These may actually be the same gathering, because one (K001235484) bears Maingay's original label, numbered 3349, along with a label applied at Kew with the herbarium number 1435, and the other (K001235485) has only the Kew label, numbered 1435. I designate as the lectotype the pistillate specimen at K (K001235486); it bears both Maingay's original label, numbered 1874, and the Kew label, numbered 1430.

19. Cyclostemon maquilingensis Merr., Philipp. J. Sci., C 9: 477 (1915 ['1914']). - Drypetes maquilingensis (Merr.) Pax \& K.Hoffm. in Engler (ed.), Pflanzenr. IV, fam. 147 (Heft 15): 240 (1922). - TYPE: Philippines, Luzon, Laguna Province, Mt Maquiling, February 1914, A. Villamil For. Bur. 20877 (lectotype US [US00109937], designated here).

Notes. Only a single gathering was cited in the protologue; I have designated as the lectotype the only syntype I have located.

20. Cyclostemon megacarpus Merr., Philipp. J. Sci., C 7: 387 (1913 ['1912']). Drypetes megacarpa (Merr.) Pax \& K.Hoffm. in Engler (ed.), Pflanzenr. IV, fam. 147 (Heft 15): 248 (1922). - TYPE: Philippines, Luzon, Laguna Province, San Antonio, June 1912, M. Ramos Bur. Sci. 14953 (lectotype A [A00055908], designated here; isolectotype BM).

= Drypetes grandifolia (C.B.Rob.) Pax \& K.Hoffm. in Engler (ed.), Pflanzenr. IV, fam. 147 (Heft 15): 245 (1922).

Notes. Only a single gathering was cited in the protologue. I have designated as the lectotype the better of the two syntypes that I could locate.

21. Cyclostemon merrittii Elmer, Leafl. Philipp. Bot. 3: 913 (1910). - TYPE: Philippines, Capiz, Sibuyan Island, Magallanes (Mt Giting-Giting), April 1910, A.D.E. Elmer 12247 (lectotype NY [NY02684320], designated here; isolectotypes BISH 
[BISH1001526*], G [G00434735, G00434736], HBG [HBG516349*], L [L0154736], MO [MO-260038*], US [US00109938]).

= Drypetes longifolia (Blume) Pax \& K.Hoffm. in Engler (ed.), Pflanzenr. IV, fam. 147 (Heft 15): 245 (1922).

Notes. Only a single gathering was cited in the protologue. I have designated the specimen at NY as the lectotype because it is among the best of the syntypes I located and it has a typed copy of Elmer's field notes attached.

22. Cyclostemon microphyllus Merr., Publ. Bur. Sci. Gov. Lab. 17:27 (1904). - Drypetes microphylla (Merr.) Pax \& K.Hoffm. in Engler (ed.), Pflanzenr. IV, fam. 147 (Heft 15): 237 (1922). - TYPE: Philippines, Luzon, Bataan Province, Lamao River, January 1904, P.T. Barnes For. Bur. 175 (neotype (or perhaps lectotype) US [US01278174], designated here; isoneotypes (or perhaps isolectotypes) BM [BM001278174], CAL [CAL0000022940*], F [V0363342F], NY, P [P05600140*]).

Notes. Only a single gathering, P.T. Barnes For. Bur. 296, is cited in the protologue. I have been unable to locate any syntypes. According to the protologue, the Barnes specimen was collected in the Philippines, in Bataan Province along the Lamao River, January 1904. I therefore have designated another Barnes collection from the same location and month as the neotype. It is interesting that Merrill (1906) did not list Barnes 296 in his catalogue of plants of the Lamao River area, nor did Pax \& Hoffmann (1922) indicate that they saw it, although both Merrill (1906) and Pax and Hoffmann (1922) cited Barnes 175. This may indicate that Merrill's (1904) citation of Barnes 296 in the protologue was in error and explain why I could not locate a duplicate, despite Barnes's collections being widely distributed. If that is the case, then Barnes 175 could well be the type gathering, with the US specimen being the lectotype rather than the neotype.

23. Cyclostemon minahassae Boerl. \& Koord., Meded. Lands Plantentuin 19: 590 (1898). - Drypetes minahassae (Boerl. \& Koord.) Pax \& K.Hoffm. in Engler (ed.), Pflanzenr. IV, fam. 147 (Heft 15): 243 (1922). - TYPE: [Indonesia], Insula Celebes [Sulawesi, Sulawesi Utara], Minahasa, S.H. Koorders 16959 (lectotype L [L0155427], designated here; isolectotype $\mathrm{K}$ [K000854241]). Remaining syntypes: same locality as lectotype, Koorders $16939 \beta$ n.v.; ibidem, Koorders 16979 (L [L0155428]); ibidem, Koorders 19585 (L [L0155425]); ibidem, Koorders 19596 (L [L0155426]).

Notes. Six gatherings were cited as syntypes in the protologue. I have designated as the lectotype the only specimen I saw with attached flowers; all the others are either sterile or have fruits in the packet. 
24. Cyclostemon mindanaensis Merr., Philipp. J. Sci., C 9: 479 (1915 ['1914']). Drypetes mindanaensis (Merr.) Pax \& K.Hoffm. in Engler (ed.), Pflanzenr. IV, fam. 147 (Heft 15): 248 (1922). - TYPE: Philippines, Mindanao, Zamboanga District, Lumbiang, 21 July 1908, V. Tarrosa For. Bur. 12458 (lectotype US [US00109939], designated here; isolectotypes K [K000854319], NY [NY02684346], P [P05600139]).

Notes. Only a single gathering was cited in the protologue; I have designated a goodquality syntype as the lectotype.

25. Cyclostemon mindorensis Merr., Philipp. J. Sci., C 9: 479 (1915 ['1914']). Drypetes mindorensis (Merr.) Pax \& K.Hoffm. in Engler (ed.), Pflanzenr. IV, fam. 147 (Heft 15): 274 (1922). - TYPE: Philippines, Mindoro, Naujan, July 1913, L. Escritor Bur. Sci. 21311 (lectotype NY [02684303], designated here; isolectotypes A [A00055909], F [F0092310F], GH [GH00055910], K [K000854272], L [L0155431], $\mathrm{P}$ [P05600137], SING [SING0050223], US [US00109940], VT [UVMVT026650*]). = Drypetes littoralis (C.B.Rob.) Merr., Philipp. J. Sci. 29: 380 (1926).

Notes. Only a single gathering was cited in the protologue. From among the many syntypes, I have designated as the lectotype the specimen at NY because it has some of the most mature fruits; fruit characters are particularly important for separating species in the Drypetes cumingii/D. littoralis/D. neglecta species group (Airy Shaw, 1975).

26. Cyclostemon monospermus Merr., Philipp. J. Sci. 1(Suppl.): 76 (1906). - Drypetes monosperma (Merr.) Pax \& K.Hoffm. in Engler (ed.), Pflanzenr. IV, fam. 147 (Heft 15): 255 (1922). - TYPE: Philippines, Luzon, Bataan Province, Lamao River, Mt Mariveles, 3 March 1905, R. Meyer For. Bur. 2802 (lectotype NY [NY02684348], designated here; isolectotypes $\mathrm{F}$ [V0363341F], K [K001235491], P [P05608716], US [US00109941]). Remaining syntypes: same locality as lectotype, June 1904, T.E. Borden For. Bur. 1225 (K [K001235490], NY, US [US00516641]); ibidem, May 1905, Meyer For. Bur. 3122 (K [K001235492], NY, US [US00516639]); ibidem, 1905, Meyer For. Bur. 3235 (NY, US [US00513068]); ibidem, April 1905, H.N. Whitford 1232 (NY, US [US00516640]).

Notes. Multiple syntypes were cited in the protologue. I have designated as the lectotype a specimen that bears the distinctive one-seeded fruits.

27. Cyclostemon neglectus Koord. in Koorders-Schumacher, Syst. Verz. 1(147): 21 (1912). - Drypetes neglecta (Koord.) Pax \& K.Hoffm. in Engler (ed.), Pflanzenr. IV, fam. 147 (Heft 15): 242 (1922). - TYPE: [Indonesia], Java, [Jawa Timur], Besuki, 1898, S.H. Koorders $30028 \beta$ (lectotype L [L.2207950, L.2207951 - one specimen over two sheets], designated here). Remaining syntypes: same locality as lectotype, 1889, 


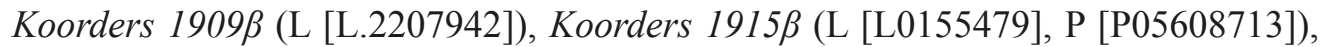
Koorders 1917 $\beta$ (L [L.2207941]), Koorders 10107 $\beta$ (L [L.2207956]); ibidem, 1892, Kooders 1912 $\beta$ (K [K000854242], L [L.2207947]); ibidem, 1895, Koorders 21205 $\beta$ (L [L.2207940]); ibidem, 1898, Kooders 30255 $\beta$ (L [L.2215042]); ibidem, s.d., Koorders $29132 \beta$ (L [L.2207952]).

Notes. Koorders (in Koorders-Schumacher, 1912) cited 18 syntypes in the protologue, all his own collections. From among those I have been able to see, I have designated as the lectotype the one with the best fruit because fruit characters putatively separate Drypetes neglecta from its close relative D. littoralis (Airy Shaw, 1975).

28. Cyclostemon nervosus Hook.f., Fl. Brit. India 5: 342 (1887). - Drypetes nervosa (Hook.f.) Pax \& K.Hoffm. in Engler (ed.), Pflanzenr. IV, fam. 147 (Heft 15): 244 (1922). - TYPE: [Malaysia], Perak, B. Scortechini 1915 (lectotype K [K000854221], designated here; isolectotypes BM [2 sheets], CAL [CAL0000022969*], E [E00394978*], SING [SING0050749, SING0050750]). Remaining syntype: same locality as lectotype, Scortechini 1015 (K [K000854222]).

Notes. When Hooker (1887) described Cyclostemon nervosus, he did not specifically cite any specimens, but wrote "Perak, Scortechini". There are two specimens at K, one staminate and the other pistillate, bearing Herbarium Mus: Perak labels saying "From Dr. King, recd. 1.1887'. The specimens at BM, CAL, E, and SING, also with Perak herbarium labels, give Scortechini as the collector. It would appear that the specimens at $\mathrm{K}$ are Scortechini specimens King sent to K from Calcutta following Scortechini's death there in 1886 (Van Steenis-Kruseman \& Van Steenis, 1950). Hooker described staminate and pistillate material, so apparently studied both specimens. I have designated the pistillate specimen at $\mathrm{K}$ as the lectotype because it shows the distinctive stipule, leaf, and ovary characteristics of this species.

29. Cyclostemon oligophlebius Merr., Philipp. J. Sci. 20:398(1922), as ‘oligophlebium'. - TYPE: Philippines, Mindoro, [Mindoro Oriental Province], Bongabong River, 21 May 1908, R. Rosenbluth For. Bur. 12210 (lectotype NY, designated here).

= Drypetes microphylla (Merr.) Pax \& K.Hoffm. in Engler (ed.), Pflanzenr. IV, fam. 147 (Heft 15): 237 (1922).

Notes. Merrill (1922) cited M.L. Merritt For. Bur. 4036 (collected on 28 March 1906 at the same location as the lectotype), as the type; I have been unable to locate any duplicates. In the protologue, Merrill (1922) also cited Rosenbluth For. Bur. 12210, the specimens of which are paratypes and therefore available for lectotypification; I have designated as the lectotype the only specimen of that collection I have located. 
30. Cyclostemon palawanensis Merr., Philipp. J. Sci., C 9: 480 (1915 ['1914’]). Drypetes palawanensis (Merr.) Pax \& K.Hoffm. in Engler (ed.), Pflanzenr. IV, fam. 147 (Heft 15): 249 (1922). - TYPE: Philippines, Palawan, Lake Manguao, 80 m, 27 April 1913, E.D. Merrill 9451 (lectotype BM [BM001191813*], designated here; isolectotypes K [K000854318], NY, US [US00109942]).

= Drypetes rhakodiskos (Hassk.) Bakh.f., Blumea 12: 62 (1963).

Notes. Only a single gathering was cited in the protologue. Of the four syntypes I located, only those at BM and NY have attached fruits; I have designated as the lectotype the specimen at BM because it is the better of the two.

31. Cyclostemon ramiflorus Merr., Philipp. J. Sci., C 7: 387 (1913 ['1912']). - Drypetes ramiflora (Merr.) Pax \& K.Hoffm. in Engler (ed.), Pflanzenr. IV, fam. 147 (Heft 15): 249 (1922). - TYPE: Philippines, Negros, Mount Marapara, 700 m, September 1909, H.M. Curran \& F.W. Foxworthy For. Bur. 13640 (lectotype US [US00109943], designated here).

= Drypetes grandifolia (C.B.Rob.) Pax \& K.Hoffm. in Engler (ed.), Pflanzenr. IV, fam. 147 (Heft 15): 245 (1922).

Notes. Only a single gathering was cited in the protologue; I have designated as the lectotype the only syntype that I could locate.

32. Cyclostemon serratus Blume, Bijdr. Fl. Ned. Ind. 599 (1826), as 'serratum'. Pycnosandra serrata (Blume) Blume, Mus. Bot. 2: 192 (1856). - Hemicyclia serrata (Blume) J.J.Sm., Meded. Dept. Landb. Ned.-Indië 10: 218 (1910). - Drypetes serrata (Blume) Pax \& K.Hoffm. in Engler (ed.), Pflanzenr. IV, fam. 147 (Heft 15): 273 (1922), nom. illeg., non D. serrata (Maycock) Krug \& Urb. (1892). - TYPE: [Indonesia], Java, Tjanjoer Province, Lowong Solassie, C.L. Blume 1305 (lectotype L [L.2204737], designated here; isolectotypes L [L.2204738, L.2204740]; probable isolectotype P [P05616813, collected by Blume, but without number]).

= Drypetes teysmannii (Hassk.) Bakh.f. \& Steenis, Blumea 8: 515 (1957).

Notes. There are three sheets of Blume 1305, the type of Cyclostemon serratus, at L, with no indication that they are the same specimen on multiple sheets. One bears an original label with complete locality data, whereas the others have labels prepared later and giving the locality only as Java; I have designated the specimen with the original label as the lectotype.

33. Cyclostemon sibuyanensis Elmer, Leafl. Philipp. Bot. 3: 914 (1910). - Drypetes sibuyanensis (Elmer) Pax \& K.Hoffm. in Engler (ed.), Pflanzenr. IV, fam. 147 (Heft 15): 247 (1922). - TYPE: Philippines, Capiz Province, Sibuyan, Magallanes (Mt Giting- 
Giting), April 1910, A.D.E. Elmer 12275 (lectotype NY [NY02684362], designated here; isolectotypes A [A00055911], BISH [BISH1001527*], BM [BM001191825*], $\mathrm{E}$ [E00394976*], F [F0092309F], G [G00434733, G00434734], GH [GH00055912], HBG [HBG516299*], K [K000854267], L [L0155879], MO [MO-260037], P [P05608703], U [U.1602138]).

Notes. Only a single gathering was cited in the protologue; I have designated the syntype at NY as the lectotype because it is good quality and is the only duplicate I found that has a typed copy of Elmer's field notes attached.

34. Cyclostemon subcrenatus Merr., Philipp. J. Sci., C 7: 388 (1913 ['1912’]). Drypetes subcrenata (Merr.) Pax \& K.Hoffm. in Engler (ed.), Pflanzenr. IV, fam. 147 (Heft 15): 274 (1922). - Hemicyclia subcrenata (Merr.) Merr., Enum. Philipp. Fl. P1. 2: 409 (1923). - TYPE: Philippines, Luzon, Batangas Province, near Santo Tomas, 200 m, 22 May 1910, F. Tamesis For. Bur. 21567 (lectotype A [A00055913], designated here; isolectotype US [US00109945]).

Notes. Only a single gathering was cited in the protologue; I have designated the specimen at $\mathrm{A}$ as the lectotype because it is in better condition than the other specimen I located.

35. Dodecastemon teysmannii Hassk., Verslagen Meded. Afd. Natuurk. Kon. Akad. Wetensch. 4: 141 (1855). - Cyclostemon teysmannii (Hassk.) Müll.Arg. in De Candolle, Prodr. 15(2): 481 (1866). - Drypetes teysmannii (Hassk.) Bakh.f. \& Steenis, Blumea 8: 515 (1957). - TYPE: [Indonesia], Java, J.E. Teijsmann s.n. (lectotype L [L.2204724], designated here; isolectotypes K [K000854234], L [L.2204723]).

Notes. There are two specimens of Drypetes teysmannii collected by Teijsmann from the Hasskarl herbarium at L, both received from Teijsmann in 1867 and in excellent condition. I have designated as the lectotype the specimen with an apparently original label saying "Dodecastemon Teysmannii" rather than the one with an apparently later label saying "Cyclostemon Teysmannii", perhaps indicating the former was seen (and labelled) by Hasskarl at the time he described the species.

36. Drypetes affinis Pax \& K.Hoffm. in Engler (ed.), Pflanzenr. IV, fam. 147 (Heft 15): 271 (1922). - Drypetes lasiogyna subsp. affinis (Pax \& K.Hoffm.) P.S.Green, J. Arnold Arbor. 67: 111 (1986). - Drypetes deplanchei subsp. affinis (Pax \& K.Hoffm.) P.S.Green, Kew Bull. 45: 239 (1990). - TYPE: Lord Howe Island, 1871, “F. Mueller" [C. Moore 46] (lectotype MEL [MEL515946*], designated here; isolectotype K [K000854304]). Remaining syntype: Lord Howe Island, J.P. Fullagar 4 (MEL515910*).

=Drypetes deplanchei (Brongn. \& Gris) Merr., J. Arnold Arbor. 32: 199 (1951). 
Notes. When Pax \& Hoffmann (1922) described Drypetes affinis, they cited "F. Müller" as the collector of the type. The specimen apparently was sent to Berlin by Mueller, but was collected by someone else; presumably it was destroyed. There are three collections in MEL that are candidates for lectotypification because they date from Mueller's time there: a staminate specimen collected by Fullagar (Fullagar 4) and two specimens collected by Moore, one (Moore 39, MEL262736*) fruiting and the other (Moore 46) staminate. Because Pax \& Hoffmann (1922) explicitly stated that they saw only staminate material, Moore 39 cannot be a syntype. Without explanation, Green (1990), followed by Forster (1997), stated that the type was collected by Moore and the B specimen destroyed, but they indicated neither a specific collection nor a herbarium with an extant specimen, so they did not lectotypify the name. Because Moore 46 has more mature flowers than Fullagar 4 and has a duplicate at K (possibly indicating a duplicate was also sent to B), I have chosen to follow Green's lead and have designated the former as the lectotype.

37. Drypetes convoluta Airy Shaw, Kew Bull. 19: 307 (1965). - TYPE: Philippines, Luzon, Cagayan Province, January 1912, M. Ramos Bur. Sci. 13810 (lectotype (or perhaps holotype) $\mathrm{K}$ [K000854312], designated here; isolectotypes (or perhaps isotypes) A [A01166343], L [L0016175], NY [NY2684306], US [US00513064]).

Notes. Airy Shaw (1965) did not explicitly designate the holotype in his original description of Drypetes convoluta, but indicated that Ramos Bur. Sci. 13810 was the type. The K specimen bears an annotation label in Airy Shaw's hand, dated 1963 and giving the new species name, the L specimen has an annotation label in another hand implying that the specimen was determined by Airy Shaw in June 1965 (around the date the species was described, therefore after the paper was submitted), and the other specimens listed above were not determined by Airy Shaw. Thus, he probably only examined the $\mathrm{K}$ specimen prior to describing this species.

38. Drypetes crassipes Pax \& K.Hoffm. in Engler (ed.), Pflanzenr. IV, fam. 147 (Heft 15): 241 (1922). - TYPE: [Malaysia], Sarawak, O. Beccari P.B. 3222 (lectotype FI [FI013344*, a single specimen over 2 sheets], designated here; isolectotypes G [G00434867], K [K000854243], P [P04815366]).

Notes. Only a single gathering was cited in the protologue. The specimen at FI, the location of Beccari's original collections (Van Steenis-Kruseman \& Van Steenis, 1950), is the most complete syntype I have seen so I have designated it as the lectotype.

39. Drypetes forbesii Pax \& K.Hoffm. in Engler (ed.), Pflanzenr. IV, fam. 147 (Heft 15): 269 (1922). - TYPE: [Indonesia], Sumatra, Lampung, Penanggungan, $600 \mathrm{ft}$ [180 m], 1881-1882, H.O. Forbes 1763 (lectotype BM [BM001191731*], designated 
here; isolectotypes BM [BM001191732*], GH [GH00055934], L [L0016180], P [P05600164, P05600165], SING [SING0050221]).

Notes. Only a single gathering was cited in the protologue; I have designated as the lectotype one of the best specimens among the many syntypes. The specimen labels state only "Sumatra" but detailed locality information and elevation were given by Moore (1925: 97). There is a second specimen collected by Forbes at L [L.2207817] with the number 1736. Although this could be an error for 1763, all the specimens numbered 1763 have pistillate flowers or very young fruits, whereas that numbered 1736 has mature fruits.

40. Drypetes gigantifolia J.J.Sm., Bull. Jard. Bot. Buitenzorg, sér. 3, 6: 89 (1924). TYPE: [Indonesia], Borneo, without exact location, Exped. A.W. Nieuwenhuis no. 1146, cult. in Hort. Borg. IX C 122, Anonymous. s.n. (probably J.J. Smith) (neotype L [L.2207828, L0449760, i.e., a sheet and an associated wood sample], designated here). = Drypetes pendula Ridl., Bull. Misc. Inform. Kew 1923: 365 (1923).

Notes. When Smith (1924) described Drypetes gigantifolia, he stated that he based it on a living plant cultivated in the Bogor Botanic Garden. I designate as the neotype a specimen at L collected from that tree and determined by Smith in 1924.

41. Drypetes glabridiscus J.J.Sm., Bull. Jard. Bot. Buitenzorg, sér. 3, 6: 83 (1924). - TYPE: [Indonesia], Bogor Botanical Garden, originally from Sulawesi, Minahasa, plants IX.C.117, Anonymous s.n. (probably J.J. Smith) (neotype L [L.2213162], designated here; isoneotype K [K000854291]).

Notes. Smith (1924) explicitly stated that his description was based on two trees cultivated at the Bogor Botanical Garden; he cited no specimens. Specimens made from both trees and identified by Smith are in the herbarium at L (one with staminate flowers and the other with fruits), with a duplicate of the staminate gathering at K. I have designated as the neotype a staminate specimen in excellent condition because Smith asserted that this species differs from its close relative Drypetes longifolia not only in some vegetative characters, but also in stamen number. He also wrote that the glabrous disc in the pistillate flowers was distinctive, but I have found that disc characters can be difficult to discern in fruits.

42. Drypetes heptandra Pax \& K.Hoffm. in Engler (ed.), Pflanzenr. IV, fam. 147 (Heft 15): 254 (1922). - TYPE: Philippines, Minanao, Zamboanga, Port Banga, JanuaryFebruary 1908, H.N. Whitford \& W.I. Hutchinson 9336 (lectotype US [US00513066], designated here). Remaining syntypes: Philippines, Luzon, Camarines, Pasacao, 1902, G.P. Ahern 27 (L [L.2207964], NY, US [US00513067, US01014062]). 
Notes. Pax \& Hoffmann (1922) cited two gatherings as syntypes. I have designated as the lectotype the only syntype I have seen that has mature flowers in good condition.

43. Drypetes hoaensis Gagnep., Bull. Soc. Bot. France 71: 259 (1924). - TYPE: Vietnam, Tay-ninh Province, mont Deon-ba, June 1866, L. Pierre s.n. (lectotype P [P05470776], designated here; isolectotype P [P05470847]). Remaining syntypes: Vietnam, Tay-ninh Province, mont Deon-ba, April 1866, Pierre s.n. (K [K000854259], P [P05470846]); monts Dinh, prope. Baria, October 1867, Pierre s.n. (P [P05470777]); Bien-hoa Proc., Gia-lo-me, dans les monts Chua-chuang, August 1865, Pierre s.n. (G [G00434863], P [P05470775, P05470845]).

Notes. Gagnepain (1924) listed Pierre gatherings from three locations as syntypes. Two specimens at P have drawings and notes by Gagnepain attached; P05470776 is staminate and P05470777 is fruiting. Because the characters of the staminate flowers are more important than those of the fruits for distinguishing this species, I have designated the staminate specimen as the lectotype.

44. Drypetes lasiogynoides Pax \& K.Hoffm. in Engler (ed.), Pflanzenr. IV, fam. 147 (Heft 15): 272 (1922). - TYPE: Kaiser Wilhemsland [Papua New Guinea], Augustafluss [Sepik River], 1887, M.U. Hollrung 722 (lectotype K [K000854311], designated here; isolectotypes HBG [HBG516317*], L [L0016184]).

Notes. Pax \& Hoffmann (1922) listed two gatherings as syntypes. I have been unable to locate specimens of one of these (C.L. Ledermann 12336) and have designated as the lectotype the best specimen I have located of the other.

45. Drypetes macrostigma J.J.Sm., Bull. Jard. Bot. Buitenzorg, sér. 3, 6: 85 (1924). - TYPE: Borneo, without locality, cult. in Hort. Bog., VIII F 63, Anonymous s.n. (probably J.J. Smith) (neotype L [L.2213134], designated here).

Notes. Smith (1924) described Drypetes macrostigma from living trees, collected by C. de Groot on Borneo and grown at the Bogor Botanical Garden. The name therefore requires neotypification. There are several candidates at L; I have designated as the neotype a specimen that has pistillate flowers with the large, reflexed stigmas that Smith thought to be diagnostic. This specimen does not have an original label but has a label applied at $L$ that associates it with another sheet there (L.2213133). That sheet has two original labels, one saying "Cyclostemon macrostigma [sic] J.J.S., 1923" and the other saying "Drypetes macrostigma J.J.S., det. 1924", but both indicating the material was collected from tree VIII F 63; the material on sheet L.2213134 apparently was originally associated with one or both of these labels. Sheet L.2213133 has two sterile twigs, some loose leaves, and a packet containing fruits. The twig on the left 
might match the flowering material on L.2213134, whereas the twig on the right and the loose leaves look different, and possibly are associated with the fruits in the packet. In any case, some or all of the material on L.2213133 is a different gathering from the material on L.2213134, probably collected in a different year, so L.2213133 should not be regarded as an isolectotype.

46. Drypetes macrostigma J.J.Sm. var. ecarinata J.J.Sm., Bull. Jard. Bot. Buitenzorg, sér. 3, 6: 86 (1924). - TYPE: [Indonesia], Sumatra, Palembang, subdiv. Banjoeasin en Koeboestreken, near Bajoeng Lintjir, 15 m, 14 September 1920, L.J.W. Dorst [A. Thorenaar] 80 E. 1 P. 913 (lectotype L [L.2213361, L.2213362, L0449089 - one specimen over two sheets and boxed fruit], designated here). Remaining syntypes: Indonesia, Sumatra, Palembang, subdiv. Banjoeasin en Koeboestreken, 30 March 1920, F.H. Endert [C.J. van der Zwaan] 80 E 1 P. 749 (L [L.2213360]); ibidem, 20 m, 15 November 1915, W. Grashoff 819 (L [L.2213393]); ibidem, February 1922, L.J.W. Dorst [A. Thorenaar] 80 E. 1 P. 913 n.v.).

Notes. Smith (1924) cited four syntypes for Drypetes macrostigma var. ecarinata; I have seen specimens of three of these. I have designated as the lectotype a fruiting specimen at L because Smith thought fruit and seed characters to be diagnostic for this taxon.

47. Drypetes microphylloides S.Moore, J. Bot. 63(Suppl.): 97 (1925). - TYPE: [Indonesia], Sumatra, Lampung, forest S.W. of Goenoeng Trang, $400 \mathrm{ft}$ [120 m], 1880, H.O. Forbes 1554 (lectotype (or possibly holotype) BM [BM001191752*], designated here; isolectotype (or possibly isotype) GH [GH00055935]).

Notes. Moore (1925) did not designate the herbarium where the type is located, but he worked at BM at the time of this publication; there is no evidence he saw the specimen at $\mathrm{GH}$. I therefore have designated as the lectotype the specimen at BM.

48. Drypetes myrmecophila Merr., Univ. Calif. Publ. Bot. 15: 141 (1929). - TYPE: [Malaysia], British North Borneo [Sabah], Elphinstone Province, Tawao [Tawau], October 1922-March 1923, A.D.E. Elmer 20965 (lectotype UC [UC290358], designated here; isolectotypes A [A00055936, A00055937], BISH [BISH1001530*], BR [BR0000005216116*], CM [CM1266*], DS [DS0033416*], G [G00434861], HBG [HBG516313*], K [K000854240], L [L0016186], M [M0265529*], NY [NY02684353], P [P05592406], PH [PH00009946*], S [S07-14644*], SING [SING0050224], U [U.1602141]).

= Drypetes longifolia (Blume) Pax \& K.Hoffm. in Engler (ed.), Pflanzenr. IV, fam. 147 (Heft 15): 245 (1922). 
Notes. In the introduction to the paper describing Drypetes myrmecophila, Merrill (1929) indicated that the "actual types" (apparently meaning holotypes) were deposited at $\mathrm{PNH}$, all of which presumably were destroyed. He also stated that isotypes were deposited at UC, so I designate the specimen there as the lectotype.

49. Drypetes palawanensis var. parvifolia Merr., Univ. Calif. Publ. Bot. 15: 141 (1929). - TYPE: [Malaysia], British North Borneo [Sabah], Elphinstone Province, Tawao [Tawau], October 1922-March 1923, A.D.E. Elmer 20587 (lectotype UC [UC290364], designated here; isolectotypes A [A00055941], B [B 10 0241085*], BR [BR0000005905935*], CAS [CAS0033414], DS [CAS0033415], GH [GH00055940], HBG [HBG516305*], K [K000854247], L [L0155708], M [M0265527*], MICH [MICH1104800*], NY [NY02684355], P [P05600476, P05608711], S [S07-14643*], SING [SING0050356], U [U.1602139]). Remaining syntypes: same collection data as lectotype, Elmer 20768 (A [A00055938, A00055939], BR [BR0000005905249*], $\mathrm{K}$ [K000854248], L [L0155709], M [M0265528*], MICH [MICH1104801*], NY [NY02684356], P [P05592403, P05608710], S [S07-14642*], SING [SING0050231], U [U.1602140], US [US01269009]).

= Drypetes rhakodiskos (Hassk.) Bakh.f., Blumea 12: 62 (1963).

Notes. Merrill (1929) listed two syntypes when he described Drypetes palawanensis var. parvifolia, and indicated in the introduction to the paper that he studied material at PNH and UC, with the "actual types" deposited at PNH and isotypes at UC. The syntypes at PNH presumably were destroyed, so I next considered specimens at UC. Only Elmer 20587 is represented there, so I have designated the duplicate there as the lectotype.

50. Drypetes pendula Ridl., Bull. Misc. Inform. Kew 1923: 365 (1923). - TYPE: [Malaysia], Perak, Larut, October 1882, King's Collector [H.H. Kunstler] 3540 (lectotype K [K000854224*], designated here; isolectotypes L [L.2208019, L.2208020 - one specimen over two sheets], SING [SING0050227]). Remaining syntypes: [Malaysia], Penang, Government Hill, February 1867, A.C. Maingay 1453 [2237] (K [K000854223], L [L.2212693]); Singapore, Seletar, 1894, H.N. Ridley 6124 (P [P05563365, P05563366], SING [SING0050227]).

Notes. Ridley (1923) cited three syntypes for Drypetes pendula. I have designated a specimen at $\mathrm{K}$ with attached fruits as the lectotype because, in addition to its very large leaves, this species is easily distinguished from its close relative, D. longifolia, by fruit characters. The other syntypes are either staminate (Maingay 1453) or, depending on the specimen, have detached or no fruits (Ridley 6124). 
51. Drypetes perakensis Gage, Rec. Bot. Surv. India 9: 223 (1922). - TYPE: [Malaysia], Perak, Larut, within $100 \mathrm{ft}$ [30 m], September 1884, King's Collector [H.H. Kunstler] 6650 (lectotype CAL [CAL0000022976*], designated here). Remaining syntypes: [Malaysia], Perak, Larut, within $100 \mathrm{ft}$ [30 m], March 1883, King's Collector [H.H. Kunstler] 3967 (CAL [CAL0000022978*]); Larut, within $100 \mathrm{ft}[30 \mathrm{~m}]$, September 1884, King's Collector [H.H. Kunstler] 6650 (CAL [CAL0000022975*]); Foot of Gunung Bubu, 300-500 ft [90-150 m], March 1885, King's Collector [H.H. Kunstler] 7423 (CAL [CAL0000022977*]); Larut, Blanda Mabok, April 1890, L. Wray 3970 (CAL [CAL0000022974*]); without exact locality, Wray 3022 (CAL [CAL0000022970*, CAL0000022971*]); ibidem, Wray 3025 (CAL [CAL0000022972*, CAL0000022973*]).

Notes. Gage (1922) cited six gatherings in the protologue. I have designated as the lectotype a specimen with attached fruits and leaves in good condition because Gage believed leaf characters distinguished Drypetes perakensis from the related Drypetes curtisii.

52. Drypetes rhakodiskos var. laevigata Airy Shaw, Kew Bull. 19: 301 (1965). TYPE: [Malaysia], Negri Sembilan, Ulu Bendol Forest Reserve, 1 December 1922, R.E. Holttum SFN 9868 (lectotype K [K001235489], designated here; isolectotypes K [K001235487, K001235488], SING [SING0050228]).

= Drypetes rhakodiskos (Hassk.) Bakh.f., Blumea 12: 62 (1963).

Notes. As Airy Shaw (1965) noted in the protologue, there are three sheets of the type collection at $\mathrm{K}$. There is no obvious indication that these constitute a single specimen on three sheets and he did not designate one of them as the holotype. I have designated as the lectotype the only fertile sheet at $\mathrm{K}$.

53. Drypetes simalurensis J.J.Sm., Bull. Jard. Bot. Buitenzorg, sér. 3, 6: 90 (1924). - TYPE: [Indonesia], Simaloer Island [Simeulue], Landschap Tapah (Dèfajan), 25 September 1919, Achmad 1404 (lectotype L [L.2204810, L.2204811 - one specimen over two sheets], designated here; isolectotype U [U.1605862]). Remaining syntypes: Indonesia, Simaloer Island [Simeulue], 3 March 1919, Achmad 955 (K [K000854281], L [L.2204768, L.2204769, L.2204770 - one specimen over three sheets], U [U.1605808]); ibidem, 15 July 1919, Achmad 1241 (L [L.2204812, L.2204813 - one specimen over two sheets], U [U.1605873]).

Notes. Smith (1924) listed three syntypes for Drypetes simalurensis. He differentiated his new species from Drypetes longifolia based on unspecified differences in the flowers and young fruits. According to Airy Shaw (1981), the species differ, if at all, in carpel number. I therefore designate as the lectotype a fruiting specimen at $\mathrm{L}$ that bears attached fruits. 
54. Drypetes simalurensis var. latifolia J.J.Sm., Bull. Jard. Bot. Buitenzorg, sér. 3, 6: 91 (1924). - TYPE: [Indonesia], Sumatra, Palembang, Onderafd. Banjoeasin en Koeboestreken, 15 m, August 1921, F.H. Endert 125 E. 1 P. 793 (lectotype L [L.2204805, L.2204806 - one specimen over two sheets], designated here). Remaining syntype: Indonesia, Sumatra, Palembang, Banjoeasin en Koeboestreken, \pm 20 m, 17 January 1916, C.W.F. Grashoff 910 (L [L.2204809]).

= Drypetes simalurensis J.J.Sm., Bull. Jard. Bot. Buitenzorg, sér. 3, 6: 90 (1924).

Notes. Smith's (1924) description of Drypetes similurensis var. latifolia was based on two syntypes; he stated that the Grashoff collection was sterile and the Endert collection was fruiting. I designate the Endert collection at L as the lectotype.

55. Drypetes subsymmetrica J.J.Sm., Bull. Jard. Bot. Buitenzorg, sér. 3, 6: 88 (1924). TYPE: [Indonesia], Simaloer Island [Simeulue], 7 March 1918, Achmad 285 (lectotype L [L.2213363], designated here). Remaining syntypes: same locality as lectotype, 16 March 1918, Achmad 303 (L [L.2213391, L.2213392 - one specimen over two sheets]); ibidem, 20 April 1918, Achmad 386 (L [L.2204712]); ibidem, 5 July 1918, Achmad 521 (L [L.2213358, L.2213359, L0449088 - one specimen over two sheets and a boxed fruit], U [U.1605863]); ibidem, 9 July 1919, Achmad 1224 (L [L.2204803, L.2204804 - one specimen over two sheets]); ibidem, 11 July 1919, Achmad 1233 (L [L.2204708]); ibidem, 13 October 1919, Achmad 1443 (L [L.2204709, L.2204710, L0449090 - one specimen over two sheets and a boxed fruit]).

Notes. Smith (1924) listed seven syntypes in the protologue. I have designated as the lectotype the best staminate specimen I have seen because characteristics of the staminate flowers can be particularly useful for distinguishing species in the Drypetes longifolia group, to which this species belongs.

56. Drypetes talamauensis J.J.Sm., Bull. Jard. Bot. Buitenzorg, sér. 3, 6: 91 (1924). - TYPE: [Indonesia], Sumatra, Ophir districts [Sumatera Barat], Talamau, $1900 \mathrm{~m}$, May 1917, H.A.B. Bünnemeijer 829 (lectotype L [L0155970]), designated here). Remaining syntypes: same locality as lectotype, 1500 m, 13 May 1917, Bünnemeijer 710 (L [L0155678]), Bünnemeijer 711 n.v.

Notes. Smith (1924) listed three specimens as syntypes of Drypetes talamauensis. I have designated as the lectotype the only fruiting specimen I located because the long fruiting pedicels are one of the most distinctive characteristics of this species (Airy Shaw, 1981; Smith, 1924). 
57. Elaeocarpus deplanchei Brongn. \& Gris, Bull. Soc. Bot. France 10: 477 (1863). - Hemicyclia deplanchei (Brongn. \& Gris) Baill. ex Guillaumin, Ann. Mus. Colon. Marseille, sér. 2, 9: 224 (1911). - Drypetes deplanchei (Brongn. \& Gris) Merr., J. Arnold Arbor. 32: 199 (1951). - TYPE: New Caledonia, 1861, E. Deplanche 463 (lectotype P [P00066731], first step designated by Green, Kew Bull. 45: 239 (1990), second step designated here; isolectotypes P [P00066732, P00066733]).

Notes. Green (1990), and after him McPherson (in McPherson \& Schmid, 1991) and Forster (1997), stated that the holotype of Elaeocarpus deplanchei was at P, but because there are three sheets of Deplanche 463 at $\mathrm{P}$, each labelled somewhat differently, Green only completed a first-step lectotypification. Two of the specimens clearly were labelled in 1951 or later because they bear the name Drypetes deplanchei in the same handwriting as E. deplanchei; the one specimen that was labelled E. deplanchei prior to 1951 , and thus probably by Brongniart and Gris, is chosen here as the second-step lectotype.

58. Hemicyclia lanceolata Thwaites, Enum. Pl. Zeyl. 287 (1861). - Drypetes lanceolata (Thwaites) Pax \& K.Hoffm. in Engler (ed.), Pflanzenr. IV, fam. 147 (Heft 15): 269 (1922). - TYPE: [Sri Lanka], Caltura [Kalutara], G.H.K. Thwaites s.n., C.P. 2211, p.p. (lectotype K [K000246674], designated here; possible isolectotypes BR [BR0000005101856*], FR [FR0031387*], K [K000246675], L [L.2208086], P [P05563368, P05563369], PDA n.v.).

= Drypetes sumatrana (Miq.) Pax \& K.Hoffm. in Engler (ed.), Pflanzenr. IV, fam. 147 (Heft 15): 270 (1922).

Notes. Thwaites (1858-1864) cited C.P. 2211 as the type of Hemicyclia lanceolata and gave the location as "Caltura", now called Kalutara, Sri Lanka. The number is a catalogue number, not a specific collection number, and I have located specimens bearing this number with collection dates from both before and after Thwaites described the species and from various locations in Sri Lanka (several also lack specific locations and/or dates). I have designated as the lectotype the best specimen I have seen that could be original material and listed as possible isolectotypes those specimens that do not bear data conflicting with the protologue.

The name Anaua sumatrana Miq., which is the basionym for Drypetes sumatrana (Miq.) Pax \& K.Hoffm., was published by Miquel (1861) in December 1861 (Stafleu \& Cowan, 1981). Thwaites (1858-1864) stated that the part of that work containing Hemicyclia lanceolata was published in 1861, but no more specific date is available. Given the lack of conclusive evidence regarding the relative publication dates, the two names should be treated as having equal priority, in which case the priority of Anaua sumatrana over Hemicyclia lanceolata was set by Chakrabarty et al. (1997), who were the first to synonymise them. 
59. Hemicyclia rhakodiskos Hassk., Verslagen Meded. Afd. Natuurk. Kon. Akad. Wetensch. 4: 140 (1855). - Pierardia rhakodiskos (Hassk.) Hassk., Bull. Soc. Bot. France 6: 713 (1860 ['1859']), as 'rhakodiscus'. - Cyclostemon rhakodiskos (Hassk.) Müll.Arg. in De Candolle, Prodr. 15(2): 484 (1866), as 'rhakodiscus'. - Drypetes rhakodiskos (Hassk.) Bakh.f., Blumea 12: 62 (1963). - TYPE: [Indonesia], Java, J.K. Hasskarl s.n. (lectotype G-DC [G00318475], designated here).

Notes. Hasskarl (1855) did not list any specimens when he described Hemicyclia rhakodiskos. Presumably there should be a specimen from the Hasskarl Herbarium at L (Van Steenis-Kruseman \& Van Steenis, 1950), but I have been unable to locate one. I designate as the lectotype a specimen at G-DC labelled "ex hb. Haßk".

60. Hydnocarpus laevis Miq., F1. Ned. Ind., Eerste Bijv. (1861 ['1860’]) 388. Cyclostemon laevis (Miq.) J.J.Sm., Icon. Bogor. 4 (1910) tt. 307-308. - Drypetes laevis (Miq.) Pax \& K.Hoffm. in Engler (ed.), Pflanzenr. IV, fam. 147 (Heft 15): 240 (1922). - TYPE: [Indonesia], Sumatra, Lampung Province, Mangala, J.E. Teijsmann H.B. 4418 (lectotype (or perhaps holotype) U [U.1602129], designated here; isolectotypes (or perhaps isotypes) K [K000854244], L [L.2208124, L.2208127]).

Notes. Miquel (1861) cited only a single gathering; I have designated as the lectotype the specimen at U, where he has generally placed types of his species (Van SteenisKruseman \& Van Steenis, 1950).

\section{Note on prior lectotypification}

Anaua sumatrana Miq., Fl. Ned. Ind., Eerste Bijv. 3: 410 (1861 ['1860’]). - Hemicyclia sumatrana (Miq.) Müll.Arg. in De Candolle, Prodr. 15(2): 488 (1866). - Drypetes sumatrana (Miq.) Pax \& K.Hoffm. in Engler (ed.), Pflanzenr. IV, fam. 147 (Heft 15): 270 (1922). - TYPE: [Indonesia], Sumatra, Lampongs [Lampung Province], Siriengkibouw, J.E. Teijsmann H.B. 4530 (lectotype CAL [CAL0000022951*], designated by Chakrabarty et al., J. Econ. Tax. Bot. 21: 274 (1997); isolectotypes L [L0016193], U [U.1602134]). Remaining syntypes: Indonesia, Sumatra, Lampongs [Lampung Province], Kebang, Teijsmann H.B. 4241 (L [L0016194, L0016195 - one specimen over two sheets], U [U.1602135, U.1602136 - one specimen over two sheets]).

Notes. When Miquel (1861) described Anaua sumatrana, he only indicated that the original material was collected by Teijsmann in Lampong Province, Sumatra. Although the material that Miquel studied presumably was deposited at U (Van SteenisKruseman \& Van Steenis, 1950), Chakrabarty et al. (1997), without explanation, cited a specimen at CAL as the "type". Under Art. 9.10 of the Shenzhen Code (Turland et al., 2018), that constitutes effective lectotypification. In addition to the lectotype and 
remaining syntype specimens listed above, there are two specimens at K (K000854236, K000854237) labelled as from the Miquel herbarium and collected by Teijsmann in Sumatra, but without an exact locality or collection numbers; these may be additional isolectotypes or remaining syntypes.

ACKNOWLEDGEMENTS. I am grateful to the Naturalis Biodiversity Center for awarding me a Temminck Fellowship, which allowed intensive study of specimens in L and U. My thanks to the curators and staff at A, CAS, DS, F, G, GH, K, L, NY, P, SING, U, UC, and US for providing access to the specimens in their care, and especially to Laura Pearce at $\mathrm{K}$ for responding to many email queries. This work would not have been possible without publicly available digitised specimens through Global Plants and individual herbarium websites and digital access to botanical literature through the Biodiversity Heritage Library and the HathiTrust emergency access program. I also appreciate guidance on some nomenclatural issues from Kanchi Gandhi, John McNeill, and Nick Turland, although they may not all agree with my decisions. Reviews by Paul Forster and an anonymous reviewer, and editorial input by David Middleton, improved the paper.

\section{References}

Airy Shaw, H.K. (1965). Notes on Malaysian and other Asiatic Euphorbiaceae. L. New species of Drypetes Vahl. Kew Bull. 19: 300-308.

Airy Shaw, H.K. (1975). The Euphorbiaceae of Borneo. Kew Bull., Addit. Ser. 4: 1-245.

Airy Shaw, H.K. (1980a). The Euphorbiaceae of New Guinea. Kew Bull., Addit. Ser. 8: 1-243.

Airy Shaw, H.K. (1980b). New Euphorbiaceae from New Guinea. Kew Bull. 34: 591-598.

Airy Shaw, H.K. (1981). The Euphorbiaceae of Sumatra. Kew Bull. 36: 239-374.

Airy Shaw, H.K. (1982). The Euphorbiaceae of Central Malesia (Celebes, Moluccas, Lesser Sunda Is.). Kew Bull. 37: 1-40.

Airy Shaw, H.K. (1983). An Alphabetical Enumeration of the Euphorbiaceae of the Philippine Islands. Kew: Royal Botanic Gardens.

Bailey, I.W. \& Smith, A.C. (1953). A new Fijian species of Calyptosepalum. J. Arnold Arbor. 34: 52-66.

Baillon, H. (1858). Étude Générale du Groupe des Euphorbiacées. Paris: Victor Masson.

Blume, C.L. (1825-1826). Bijdragen tot de Flora van Nederlandsch Indië. Batavia: Lands Drukkerij.

Chakrabarty, T., Gangopadhyay, M. \& Balakrishnan, N.P. (1997). The genus Drypetes (Euphorbiaceae) in the Indian subcontinent. J. Econ. Taxon. Bot. 21: 251-280.

Elmer, A.D.E. (1911). Euphorbiaceae collected on Palawan Island. Leafl. Philipp. Bot. 4: 1271-1306.

Forster, P.I. (1997). A taxonomic revision of Drypetes Vahl (Euphorbiaceae) in Australia. Austrobaileya 4: 477-494.

Gage, A.T. (1922). Euphorbiaceae novae e peninsula malayana. Rec. Bot. Surv. India 9: 219249.

Gagnepain, F. (1924). Euphorbiacées nouvelles (Drypetes). Bull. Soc. Bot. France 71: 257-262.

Green, P.S. (1990). Notes relating to the floras of Norfolk and Lord Howe Islands, III. Kew Bull. 45: 235-255. 
Hasskarl, J.K. (1855). Brief van den heer Hasskarl. Verslagen Meded. Afd. Naturrk. Kon. Akad. Wetensch. 4: 135-141.

Hooker, J.D. (1887). The Flora of British India, vol. 5. London: L. Reeve \& Co.

Koorders-Schumacher, A. (1912). Systematisches Verzeichnis, I Abt., 1, lief. 6. Batavia: published by the author.

McNeill, J. (2014). Holotype specimens and type citations: general issues. Taxon 63: 11121113.

McPherson, G. \& Schmid, M. (1991). Euphorbiaceae. II. Phyllanthoideae. Flore de la NouvelleCalédonie et Dépendances, vol. 17. Paris: Muséum National d'Histoire Naturelle.

Merrill, E.D. (1904). New or noteworthy Philippine plants, II. Publ. Bur. Sci. Gov. Lab. 17: $5-47$.

Merrill, E.D. (1906). The flora of the Lamao forest reserve. Philipp. J. Sci. 1(suppl. 1): 1-141.

Merrill, E.D. (1914). Plantae Wenzelianae, II. Philipp. J. Sci., C 9: 353-389.

Merrill, E.D. (1915). Genera and species erroneously credited to the Philippine flora. Philipp. J. Sci., C 10: 171-194.

Merrill, E.D. (1922). New or noteworthy Philippine Plants, XVII. Philipp. J. Sci. 20: 367-476.

Merrill, E.D. (1923). An Enumeration of Philippine Flowering Plants, vol. 2. Manila: Philippine Bureau of Printing.

Merrill, E.D. (1929). Plantae Elmerianae Borneenses. Univ. Calif. Publ. Bot. 1: 1-316.

Miquel, F.A.W. (1861). Flora van Nederlandsch Indië, Eerste Bijvoegsel. Amsterdam: C.G. van der Post.

Moore, S.L.M. (1925). Monochlamydeae. In: Rendle, A.B. (ed.) Dr. H.O. Forbes's Malayan plants. J. Bot. 63, suppl.: 89-105.

Pax, F. \& Hoffmann, K. (1922). Euphorbiaceae-Phyllanthoideae-Phyllantheae. In: Engler, A. (ed.) Das Pflanzenreich, IV, 147. XV (heft 81), pp. 1-349. Leipzig: Verlag der Wilhelm Engelmann.

Ridley, H.N. (1923). New Euphorbiaceae from the Malay Peninsula. Bull. Misc. Inform. Kew 1923: 360-369.

Robinson, C.B. (1908). Alabastra philippinensia, II. Philipp. J. Sci., C 3: 175-218.

Sleumer, H. (1954). Flacourtiaceae. Flora Malesiana, ser. 1, Seed Plants, vol. 5. Djakarta: Noordhoff-Kolff N.V.

Smith, J.J. (1924). Plantae novae vel criticae ex herbario et horto bogoriensi. III. Bull. Jard. Bot. Buitenzorg, ser. 3, 6: 73-107.

Stafleu, F.A. \& Cowan, R.S. (eds) (1981). Taxonomic literature: a selective guide to botanical publications and collections with dates, commentaries and types. 2nd edition. Volume III: Lh-O. [Regnum Vegetabile, vol. 105] Utrecht: Bohn, Scheltema \& Holkema.

Thiers, B. (continuously updated). Index Herbariorum: A global directory of public herbaria and associated staff. New York Botanical Garden. http://sweetgum.nybg.org/science/ $\mathrm{ih} /$. Accessed 14 May 2021.

Thwaites, G.H.K. (1858-1864). Enumeratio Plantarum Zeylaniae. London: Dulau \& Co.

Turland, N.J., Wiersema, J.H., Barrie, F.R., Greuter, W., Hawksworth, D.L., Herendeen, P.S., Knapp, S., Kusber, W.-H., Li, D.-Z., Marhold, K. et al. (eds) (2018). International Code of Nomenclature for algae, fungi, and plants (Shenzhen Code) adopted by the Nineteenth International Botanical Congress Shenzhen, China, July 2017. Regnum Vegetabile, vol. 159. Glashütten: Koeltz Botanical Books.

Van Steenis-Kruseman, M.J. \& Van Steenis, C.G.G.J. (1950). Malaysian plant collectors and collections: being a cyclopaedia of botanical exploration in Malaysia and a guide to the concerned literature up to the year 1950. Flora Malesiana, ser. 1, Seed Plants, vol. 1. Djakarta: Noordhoff-Kolff N.V. 